Available online at http://journal.stkip-andi-matappa.ac.id/index.php/histogram/index Histogram: Jurnal Pendidikan Matematika ., 2019, 263 - 275

\title{
BERPIKIR KRITIS SISWA PADA PERMASALAHAN MATEMATIKA DENGAN LITERASI MATEMATIS
}

\author{
Restu Ria Wantika ${ }^{1}$, Reni Tri Anggraini ${ }^{2}$ \\ ${ }^{1,2}$ Universitas PGRI Adi Buana Surabaya \\ * Corresponding Author. Email: restu@unipasby.ac.id
}

Received: 8 Agustus 2019; Revised: 18 Agustus 2019 ; Accepted: 30 September 2019

\begin{abstract}
ABSTRAK
Proses berpikir kritis siswa tentunya berbeda tergantung pada kemampuan matematika masing-masing siswa. Kemampuan matematika dikenal sebagai kemampuan literasi matematika. kemampuan ini memengaruhi proses penyelesaian masalah matematika. Penelitian yang dilakukan bertujuan untuk melakukan pendeskripsikan proses pemikiran kritis siswa pada permasalahan matematika dalam hal literasi matematika. Penelitian yang digunakan deskriptif kualitatif dengan menggunakan wawancara berbasis tes. Subjek yang digunakan terdiri dari tiga siswa menengah pertama kelas VIII SMP Negeri 3 Waru, 1 siswa laki-laki tingkat 1 kemampuan apa yang ditulis, 1 perempuan tingkat 2 kemampuan melihat apa yang tertulis, dan 1 perempuan 3 kemampuan melihat apa yang tertulis. Alat penilaian yang digunakan terdiri dari tes kemampuan literasi matematika dalam bentuk PISA, item tes untuk penyelesaian permasalahan matematika dalam persamaan garis lurus, serta pedoman wawancara terstruktur. Penganalisisan data menggunakan indikator pemikiran kritis FRISCO dengan empat urutan penyelesaian permasalahan Polya. Hasil penelitian menunjukkan bahwa Proses berpikir kritis siswa dengan kemampuan literasi setiap level dalam menyelesaikan masalah matematika pada materi persamaan garis lurus meliputi: level1 dan level-2 belum mampu berpikir kritis. Pada level-3 ini siswa mampu berpikir kritis.

Kata kunci: Berpikir Kritis, Permasalahan Matematika

How to Cite: Wantika, R, R.,.\& Anggriani, R, T. (2019). Berpikir Kritis pada Permasalahan Matematika dengan Literasi Matematis. Histogram: Jurnal Pendidikan Matematika, 3(2), 263 - 275 , doi: http://dx.doi.org/10.31100/histogram.v3i2.563.

Permalink/DOI: http://dx.doi.org/10.31100/histogram.v3i2.563
\end{abstract}

\section{PENDAHULUAN}

Pada era globalisasi ini pendidikan menjadi hal sangat penting bagi kualitas manusia khususnya di Indonesia. Siswa lebih dituntut untuk memiliki kemampuan untuk berpikir logis, sistematis, kritis, kreatif serta memiliki kemampuan bekerja sama yang baik dalam kelompok. Kurikulum 2013 ini siswa diwajibkan aktif dalam proses pembelajaran baik secara individu ataupun kelompok. Untuk membekali proses tersebut, pendidik harus melatih serta membiasakan siswa untuk memiliki pemikiran tingkat tinggi yaitu salah satunya berpikir kritis. Menurut Fisher (Nisa, 2016) critical thinking (berpikir kritis) merupakan proses berpikir yang secara tidak langsung mengarah siswa langsung ke kesimpulan, atau menerima dengan beberapa bukti, berpikir kritis dengan jelas menuntut interprestasi serta evaluasi terhadap observasi yang telah dilakukan, komunikasi antar siswa, guru dan sumber-sumber keterangan lainnya yang digunakan dalam proses pembelajaran. Pada proses pembuatan rancangan dalam proses pembelajaran yang digunakan untuk mengembangkan kemampuan berpikir kritis siswa, hal yang harus

This is open access article under the CC-BY-SA-license. 


\section{Histogram: Jurnal Pendidikan Matematika, 3 (2), 2019 - 264 Restu Ria Wantika ${ }^{1}$, Reni Tri Anggraini ${ }^{2}$}

dilakukan guru salah satunya adalah melihat bagaimana proses berpikir kritis yang dimiliki siswa. Untuk melihat proses tersebut guru dapat melihat dari aktivitas pada saat proses pembelajaran dalam memecahkan permasalahan dalam soal. Ennis (Cahyono, 2017) mengemukakan bahwa terhadap hubungan antara berpikir kritis dengan bagaimana melakukan penyelesaian permasalahan matematika.

National Council of Teachers of Mathematics (NCTM) menetapkan bahwa untuk mencapai standar isi, siswa harus memiliki lima kemampuan utama dalam matematika yaitu kemampuan pemecahan masalah, penalaran, komunikasi, penelusuran pola atau hubungan, dan representasi (NCTM (Ulya, 2016). Menurut (Holis \& Sahidin, 2016) saat ini terdapat dua assessment utama berskala internasional yang menilai kemampuan matematika dam sains siswa, yaitu TIMSS (Trend in Internasional Mathematics and Science Study) dan PISA (Program for Internasional Student Assessment). Menurut Munayati (Holis \& Sahidin, 2016) pada tahun 2003 Indonesia menempati peringkat ke-38 dari 40 negara peserta, pada tahun 2006 Indonesia menempati peringkat ke-50 dari 57 negara peserta, pada tahun 2009 Indonesia menempati peringkat ke-61 dari 65 negara peserta, dan pada tahun 2012 Indonesia menempati peringkat ke-64 dari 65 negara peseta. Aspek pentingnya dari kemampuan literasi matematis dengan soal PISA dalam berpikir kritis siswa.

Menurut Wilkens (Styawati \& Nursyahida, 2017) Tujuan utama dari PISA adala untuk melakukakan penilaian sejauh mana siswa berusia 15 tahun di negara OECD ( dan negara lainnya) memperoleh kecakapan yang tepat dalam melihat apa yang tertulis, matematika dan ilmu pengetahuan untuk membuat kontribusi yang bermanfaat terhadap masyarakat secara luas.

Penelitian yang dilakukan bertujuan untuk melakukan analisis kemampuan siswa dalam menyelesaiakan permasalahan matematika. Penelitian dilakukan di SMP Negeri 3 Waru karena setelah dilakukan pengamatan terdapat kendala yang sering dihadapi oleh guru dalam tatap muka pembelajaran matematika yaitu siswa dalam proses pembelajaran masih ada yang tidak memperhatikan guru, ada siswa tidur saat proses pembelajaran, siswa belum dapat aktif dalam proses pembelajaran dan banyak siswa yang aktif hanya siswa tertentu saja, siswa yang lain hanya mengikuti saja. Guru juga hanya memberikan materi dan rumus - rumus saja memberi latihan. Pada saat proses tatap muka pembelajaran siswa hanya menjadi sebagai pendengar saja, maka dari itu siswa kurang aktif dalam proses pembelajaran. 


\section{Histogram: Jurnal Pendidikan Matematika, 3 (2), 2019 - 265 Restu Ria Wantika ${ }^{1}$, Reni Tri Anggraini ${ }^{2}$}

DePorter \& Hernacki (Maulana, 2017) cara berpikir kritis manusia dikelompokkan dalam tujuh bagian, yaitu: berpikir vertikal, berpikir lateral, berpikir kritis, berpikir analitis, berpikir strategis, berpikir tentang hasil, dan berpikir kreatif. Menurut keduanya berpikir kritis adalah berlatih atau melakukan penilaian atau evaluasi yang cermat. Menurut Ennis (Cahyono, 2017) Dasar penilaian yang harus dimiliki oleh pemikir kritis dalam memecahkan suatu masalah yang dihadapi adalah Focus, Reason, Inference, Situation, Clarity, and Overview yang dapat disingkat dengan istilah FRISCO.

Dengan menggunakan dasar penilaian berpikir kritis menurut Ennis (Cahyono, 2017) yaitu FRISCO : Focus, Reason, Inference, Situation, Clarity, Overview. Dalam penelitian ini langkah langkah menggunakan pemecahan masalah Polya

Tabel 1. Indikator Berpikir Kritis pada setiap Langkah-Langkah Penyelesaian Permasalahan Polya

\begin{tabular}{lll}
\hline \multicolumn{1}{c}{$\begin{array}{c}\text { Langkah } \\
\text { Penyelesaian }\end{array}$} & $\begin{array}{c}\text { Dasar } \\
\text { Penilaian } \\
\text { Permasalahan }\end{array}$ & $\begin{array}{c}\text { Berpikir } \\
\text { Kritis }\end{array}$ \\
\hline Memahami & Fokus & Memahami Permasalahan yang diberikan dan \\
Masalah & $($ Focus $)$ & memfokuskan permasalahan pada soal yang diberikan \\
\hline Merencanakan & Alasan & Melakukan pengkaitan keterangan - keterangan yang \\
Penyelesaian & (Reason) & didapat dengan pengetahuan terdahulu \\
\cline { 2 - 3 } Permasalahan & Kesimpulan & Menggunakan cara yang tepat dalam penyelesaian \\
& $($ Inference $)$ & permasalahan yang sesuai dengan pengetahuan yang \\
& & telah diperoleh \\
\hline Melakukan & Situasi & Melakukan penyelesaian permasalahan berdasarkan \\
rencana untuk & (Situation) & langkah - langkah yang yang telah ditetapkan \\
Penyelesaian & & \\
Permasalahan & & \\
\hline
\end{tabular}

Kejelasan Pendeskripsikan penggunaan simbol, istilah, sifat atau

(Clarity) aturan yang digunakan dalam penyelesaian permasalahan 


\section{Histogram: Jurnal Pendidikan Matematika, 3 (2), 2019 - 266 \\ Restu Ria Wantika ${ }^{1}$, Reni Tri Anggraini ${ }^{2}$}

\begin{tabular}{lll}
\hline Memeriksa & Tinjauan & Melakukan pemeriksaan kembali langkah-langkah \\
Kembali & ulang & yang digunakanakan untuk mendapatkan hasil dari \\
& (Overview) & penyelesaian permasalahan
\end{tabular}

(Sumber: Cahyono, Tahun: 2017)

Berdasarkan paparan diatas, peneliti tertarik untuk melakukan penelitian mengenai kemampuan literasi matematis dalam soal PISA untuk kemampuan berpikir kritis siswa dalam Penyelesaian Permasalahans matematika yang niatnya diharapkan bisa membuktikan kebenarannya. Berdasarkan hal tersebut, penulis mengambil penelitian yang berjudul "Proses Berpikir Kritis Siswa Dalam Penyelesaian Permasalahan Matematika Ditinjau Dari Literasi Matematis".

\section{METODE PENELITIAN}

Penelitian ini dirancang untuk melakukan pendeskripsikan proses berpikir kritis siswa sekolah menengah pertama dalam penyelesaian permasalahan matematika. Jenis penelitian ini termasuk penelitian deskriptif kualitatif dirancang untuk memahami dan mendapatkan keterangan-keterangan yang sesuai dialami siswa dengan menuliskan dalam bentuk deskripsi bahasa yang baik.

Penelitian dilakukan di sekolah SMP Negeri 3 Waru semester gasal tahun ajaran 2019/2020. Data diperoleh dari subjek yang telah mempelajari materi yang sudah didapat sebelumnya. Subjek dilakukan dengan mengelompokkan dari siswa dalam level kemampuan literasi matematis sesuai dengan hasil soal kemampuan literasi matematis berbentuk PISA. Subjek diambil perwakilan dari level kemampuan literasi matematis yaitu kemampuan literasi level-1, level-2 dan level-3. Setelah didapat subjek dengan kemampuan literasi matematis. Kemudian subjek dilakukan tes soal pemecahan masalah dengan materi persamaan garis lurus untuk mengetahui pemikiran proses berpikir kritis siswa. Kemudian diwawancarai untuk mengetahui detail siswa dalam kriteria berpikir kritis.

Teknik pengumpulan data meliputi : Tes tulis dilakukan 2 kali kepada subjek yang telah menerima materi dalam penelitian ada dua jenis tes, yatu : tes soal yang berbentuk PISA dan tes penyelesaian permasalahan matematika. Tes soal yang berbentuk PISA digunakan untuk mengelompokkan siswa dalam level kemampuan literasi matematis. Sedangkan tes penyelesaian permasalahan matematika digunakan untuk mendapatkan data proses berpikir kritis siswa dalam pernyelesaian permasalahan matematika dengan kemampuan literasi matematis. Wawancara pada penelitian dilakukan setelah subjek mengerjakan soal tes penyelesaian permasalahan matematika. Wawancara dilakukan untuk 


\section{Histogram: Jurnal Pendidikan Matematika, 3 (2), 2019 - 267 \\ Restu Ria Wantika ${ }^{1}$, Reni Tri Anggraini ${ }^{2}$}

mendapatkan gambaran lebih detail dalam berpikir kritis siswa sekolah menengah dalam penyelesaian permasalahan matematika yang sesuai dengan kriteria berpikir kritis yaitu :fokus(focus), alasan (reason), kesimpulan (inferensi), situasi (situation), kejelasan (clarity), dan meninjau ulang (overview).

Menurut (Sugiyono, 2017) Triangulasi teknik untuk pengujian kredibilitas data dengan melakukan pengecekan data kepada sumber yang sama dan menggunakan teknik yang berbeda. Untuk melakukan pengecekan tersebut digunakan 2 soal tes dan wawancara. Teknik pengumpulan data ini pertama melakukan tes kemampuan literasi matematis yang berbentuk PISA, kemudian tes soal pemecahan masalah yang terakhir dilakukan wawancara. Jika dengan tiga teknik penguji kredibilitas didapatkan hasil yang berbeda. Maka peneliti akan berdiskusi lebih lanjut untuk melakukan pengambilan data kembali atau memastikan data mana yang dianggap benar.

\section{HASIL DAN PEMBAHASAN}

Pengambilan data di kelas VIII-A SMPN 3 Waru. TKLM diberikan untuk diujikan kepada 32 siswa. Diperoleh 15 siswa berkemampuan literasi level-1, 14 siswa berkemampuan literasi level-2 dan 3 siswa yang berkemampuan literasi level-3. Setelah itu pengambilan subjek diambil berdsrkan hasil yang mendekati indikator kemampuan literasi matematis.

Setelah proses penganalisisan data, diperoleh proses berpikir kritis siswa dalam Penyelesaian Permasalahan Matematika pada materi Persamaan Garis Lurus dengan kemampuan literasi matematis sebagai berikut

\section{A. Hasil Penelitian}

1. Proses Berpikir Kritis Siswa dalam Penyelesaian Permasalahan Matematika dengan kemampuan Literasi Matematis Level-1

Siswa kemampuan literasi matematis level-1 sudah menyelesaikan soal kemampuan pemecahan masalah pada materi PGLyang diberikan memiliki durasi waktu pengerjaan sama seperti yang diterapkan disekolah yaitu 60 menit. Siswa memerlukan durasi waktu yang lebih lama untuk melihat apa yang tertulis pada soal serta mengerti maksud dari permasalahan yang ada pada soal. Siswa yang memiliki kemampuan literasi matematis level-1 ini tidak tuntas pada pencapaian indikator berpikir kritis pada setiap soal yang diberikan. Siswa bisa melihat apa yang tertulis pada soal sekitar lima sampai enam kali sehingga dapat mengerti permasalahan yang ada pada soal nomor 1, 2, serta 3 . 


\section{Histogram: Jurnal Pendidikan Matematika, 3 (2), 2019 - 268 \\ Restu Ria Wantika ${ }^{1}$, Reni Tri Anggraini ${ }^{2}$}

Siswa kurang mampu mengidentifikasi apa saja keterangan yang diberikan dalam soal. Namun siswa bisa menyebutkan apa yang diinginkan pada soal. Siswa mampu mengutarakan ide untuk menyelesaikan permasalahan dengan menggunakan rumus pada nomor 1 saja. Pada nomor 2 dan 3 siswa hanya mampu mengerjakan dengan menalar yang diketahui siswa. Dan siswa tidak bisa menjelaskan alur penyelesaiannya. Ini menyatakan bahwa siswa kurang bisa melakukan perencanaan dalam penyelesaian permasalahan dengan ide siswa sendiri, siswa hanya bisa menalar yang diketahui saja. siswa tidak bisa memberikan argumen mengapa melakukan proses pengerjaan tersebut, serta siswa hanya bisa menyelesaikan dengan pengetahuan yang siswa ketahui.

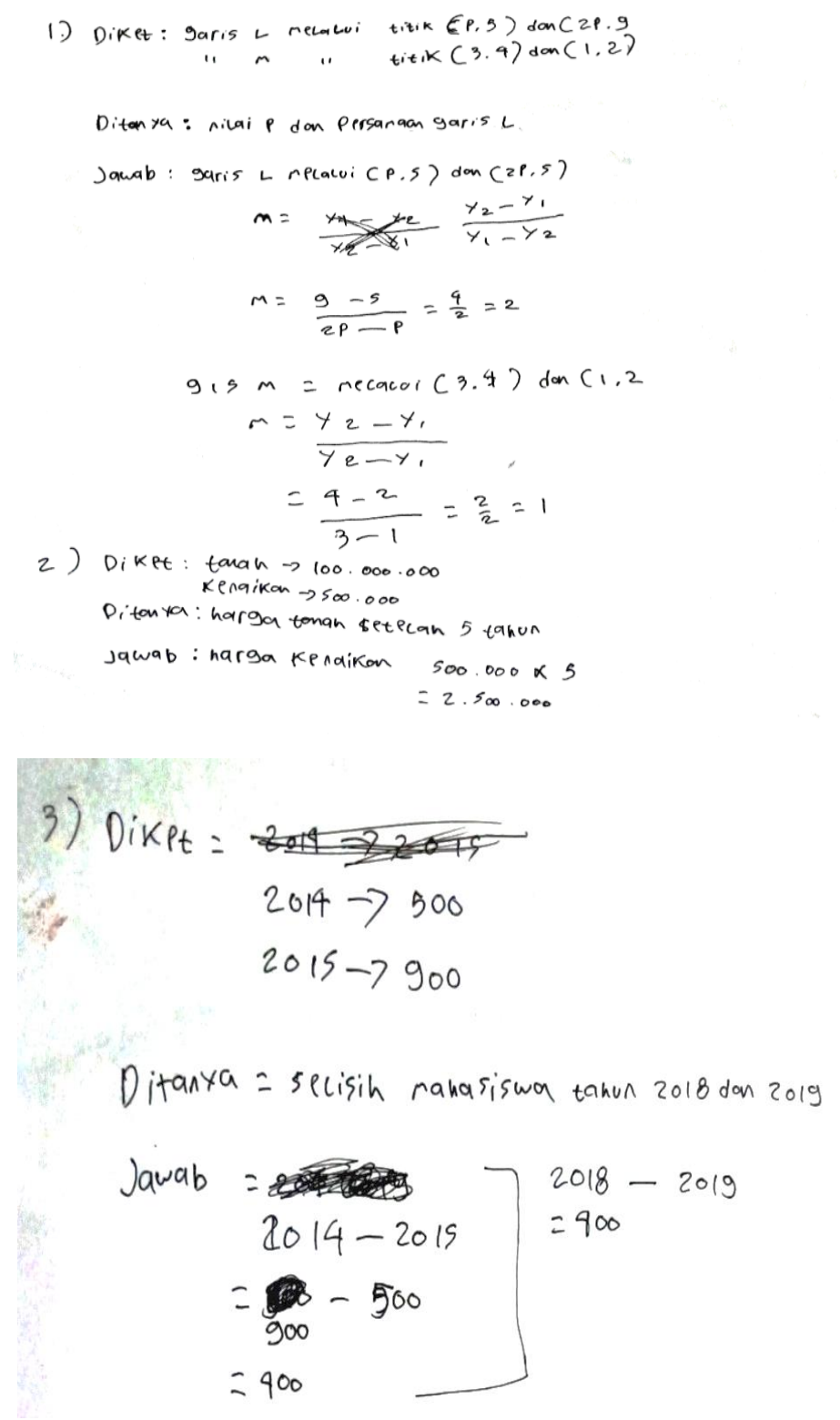

Gambar 1. Hasil Pengerjaan siswa level 1 


\section{Histogram: Jurnal Pendidikan Matematika, 3 (2), 2019 - 269 \\ Restu Ria Wantika ${ }^{1}$, Reni Tri Anggraini ${ }^{2}$}

2. Proses Berpikir Kritis Siswa dalam Penyelesaian Permasalahan Matematika dengan kemampuan Literasi Matematis Level-2

Siswa berkemampuan literasi level-2 dapat menyelesaikan tiga soal pada materi PGL yang diberikan oleh guru. Pada saat proses pemberian soal PGL memiliki durasi waktu pengerjaan sama seperti yang diterapkan disekolah yaitu 60 menit, siswa bisa memberi jawaban ketiga butir soal yang diberikan meskipun hasil penyelesaiannya pada soal nomor 1 dan 2 kurang tepat. Pada saat wawancara siswa juga memberi jawaban hasil pengerjaannya secara jelas. Siswa berkemampuan literasi level-2 ini juga memenuhi semua indikator kriteria berpikir kritis pada nomor 2 dan 3 siswa tidak dapat mengidentifikasi keterangan lainnya. Siswa melihat apa yang tertulis dari soal sekitar 3-4 kali untuk mengidentifikasi keterangan secara tepat. Siswa mampu mengidentifikasi keterangan apa yang diberi dari soal secara tepat serta mengetahui apa akan dikerjakan pada soal tersebut. Tetapi, pada nomor 3 siswa penyelesainnya hanya dengan penalaran. Dan pada nomor 2 dan 3 tidak mampu mengidentifikasi keterangan lainnya. Siswa pada merencanakan penyelesaian nomor 2 dan 3 tidak mampu merencanakan strategi untuk menyelesaikan soal siswa hanya bisa merencanakan strategi pada nomor 1. Siswa mampu menjelaskan pelaksanakan pemecahan masalah meskipun hasil penyelesaiannya kurang tepat. Namun pada nomor 3 siswa hanya mengerjakan dengan penalaran. Siswa hanya bisa mengketerangankan arti dari simbol- simbol yang ada pada soal nomor 1 dan 2 saja, untuk nomor 3 siswa tidak mampu mengketerangankan arti dari simbol- simbol. Pada saat proses wawancara, siswa mengketerangankan cara pengerjaannya meskipun jawabannya kurang tepat dan siswa tidak dapat mengketerangankan cara lain yang bisa digunakannya. .Siswa sudah yakin dengan hasil pengerjakannya. Dan siswa telah melakukan pengecekan kembali dari hasil perhitungan yang dilakukannya. 
Histogram: Jurnal Pendidikan Matematika, 3 (2), 2019 - 270

Restu Ria Wantika ${ }^{1}$, Reni Tri Anggraini ${ }^{2}$

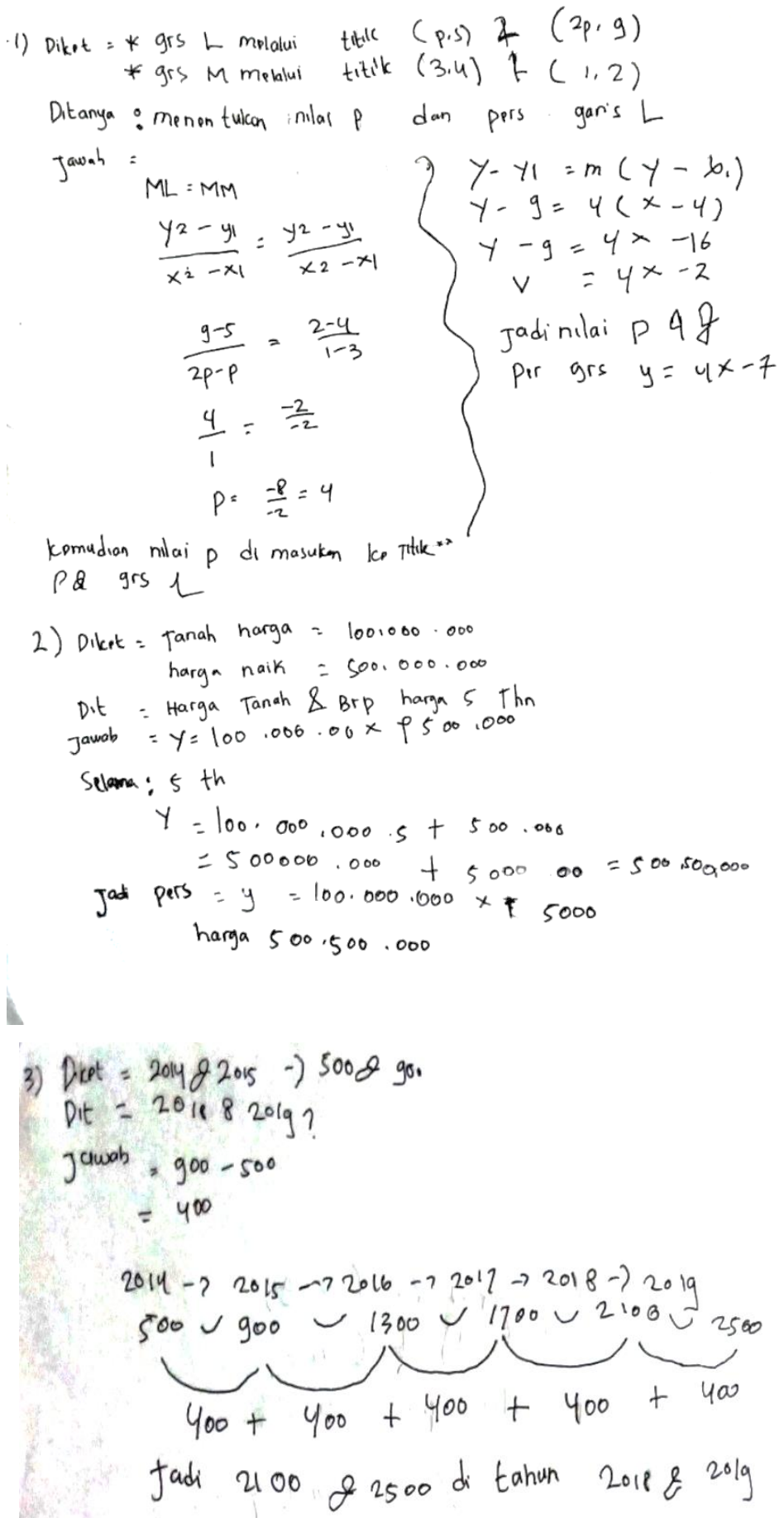

Gambar 2. Hasil Pengerjaan siswa level 2 


\section{Histogram: Jurnal Pendidikan Matematika, 3 (2), 2019 - 271 \\ Restu Ria Wantika ${ }^{1}$, Reni Tri Anggraini ${ }^{2}$}

3. Proses Berpikir Kritis Siswa dalam Penyelesaian Permasalahan Matematika dengan kemampuan Literasi Matematis Level-3

Siswa berkemampuan literasi level-3 dapat menyelesaikan tiga soal pada materi PGL yang diberikan oleh guru. Pada saat proses pemberian soal PGL memiliki durasi waktu pengerjaan sama seperti yang diterapkan disekolah yaitu 60 menit, siswa dapat memberikan jawaban utuk ketiga butir soal yang diberikan dengan tepat. Pada proses wawancara siswa juga dapat memberikan jawaban secara jelas. Siswa berkemampuan literasi level-3 ini juga memenuhi semua indikator kriteria berpikir kritis pada nomor 2 siswa tidak dapat mengidentifikasi keterangan yang lainnya. Siswa melihat apa yang tertulis pada soal sebanyak tiga kali untuk melakukan pemahaman maksud dari soal dengan tepat. Siswa bisa mengidentifikasi keterangan tentang apa yang dimaksud pada soal dengan tepat serta apa yang diingin dikerjakan pada soal. Tetapi, pada nomor 3 siswa hasil penyelesainnya hanya dengan penalaran. Dan pada nomor 2 dan 3 tidak bisa mengidentifikasi keterangan -keterangan lainnya. Siswa pada level-3 ini mampu merencanakan penyelesaian tetapi untuk 3 siswa mampu merencanakan strategi dengan cara membuat tabel. Siswa mampu menjelaskan pelaksanakan pemecahan masalah dengan tepat. Tetapi, pada nomor 3 siswa tidak bisa menjelaskan aturan/rumus yang digunakan. Siswa hanya bisa menjelaskan makna simbol- simbol yang terdapat pada soal nomor 1 dan 2 saja, untuk nomor 3 siswa tidak mampu mengketerangankan arti dari simbol- simbol. Pada saat proses wawancara, siswa mengketerangankan cara pengerjaannya serta mendapatkan hasil yang tepat dan siswa tidak dapat mengketerangankan cara pengerjaan lainnya. Siswa sudah yakin dengan hasil pengerjakannya. Dan siswa telah melakukan pengecekan kembali dari hasil perhitungan yang dilakukannya. 


\section{Histogram: Jurnal Pendidikan Matematika, 3 (2), 2019 - 272}

Restu Ria Wantika ${ }^{1}$, Reni Tri Anggraini ${ }^{2}$
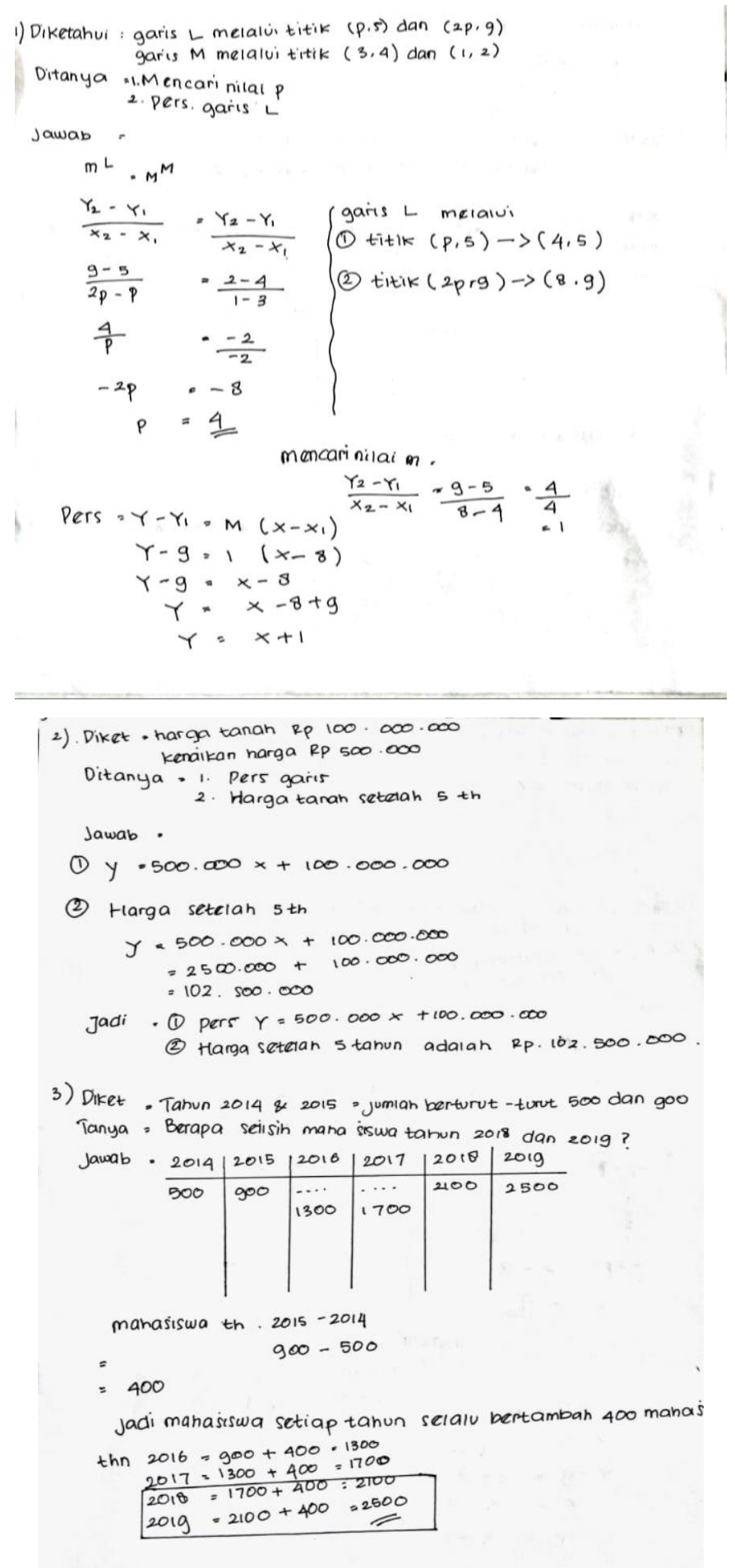

Gambar 3. Hasil Pengerjaan siswa level 3

\section{B. Pembahasan}

Menurut Ennis (Cahyono, 2017) ada beberapa kriteria berpikir kritis yaitu FRISCO: fokus (focus), alasan (reason), kesimpulan (inferensi), situasi (situation), 


\section{Histogram: Jurnal Pendidikan Matematika, 3 (2), 2019 - 273 \\ Restu Ria Wantika ${ }^{1}$, Reni Tri Anggraini ${ }^{2}$}

kejelasan (clarity), dan meninjau ulang (overview). Berdasarkan hasil penelitian yang telah dilakukan terlihat bahwa siswa memenuhi aspek dari berpikir kritis tetapi tidak semuanya maksimal. Pada siswa dengan Level-1 mampu mengidentifikasi apa saja keterangan yang diberikan dalam soal dan siswa hanya bisa menalar yang diketahui saja tetapi kurang maksimal dan siswa tidak bisa memberikan argumen mengapa melakukan proses pengerjaan tersebut, serta siswa hanya bisa menyelesaikan dengan pengetahuan yang siswa ketahui. Level 2 Siswa mampu menjelaskan pelaksanakan pemecahan masalah meskipun hasil penyelesaiannya kurang tepat tetapi tidak mampu mengketerangankan arti dari simbol- simbol dan level 3 Siswa mampu menjelaskan pelaksanakan pemecahan masalah, mampu mengketerangankan arti dari simbol- simbol dan memeriksa kembali hasil pengerjaannya.

\section{KESIMPULAN DAN SARAN}

\section{A. Kesimpulan}

Berdasarkan hasil analisis data yang telah dilakukan didapatkan beberapa kesimpulan antara lain: (1) Proses berpikir kritis siswa yang berkemampuan literasi level1 : siswa tidak bisa berpikir kritis dalam penyelesaian permasalahan pada materi PGL karena dalam proses berpikir yang dilakukan oleh siswa, siswa hanya mencapai tahapan mengetahui focus dari permasalahan yang disajikan oleh guru. Siswa hanya bisa menjawab satu nomor soal dengan benar dari 3 pertanyaan. Jadi siswa berkemampuan literasi level-1 belum melakukan evaluasi atau penilaian pada cara berpikirnya sendiri; (2) Proses berpikir kritis siswa yang berkemampuan literasi level-2: siswa tidak dapat berpikir kritis dalam penyelesaian permasalahan pada materi PGL siswa berada pada tahap mengetahui dari permasalahan yang disajikan oleh guru, siswa berada pada tahapan mengetahui alasan karena hanya pada nomor 1, untuk nomor 2 dan 3 siswa tidak mampu menentukan strategi dalam memecahkan masalah,siswa hanya mengerjakan dengan penalaran saja. Namun siswa berkemampuan level-2 ini selalu meninjau kembali hasil penyelesaiannya. Jadi siswa berkemampuan literasi level-2 belum melakukan evaluasi atau penilaian pada cara berpikirnya sendiri dan (3) Proses berpikir kritis siswa yang berkemampuan literasi level3: siswa dapat berpikir kritis dalam penyelesaian permasalahan pada materi PGL karena pada proses berpikirnya siswa berada pada tahapan mengetahu focus dari permasalahan yang disajikan, mengetahui alasan yang digunakan dan mampu menjelaskan, dapat melakukan penarikan kesimpulan dengan benar. Meskipun pada nomor 3 siswa tidak 


\section{Histogram: Jurnal Pendidikan Matematika, 3 (2), 2019 - 274 \\ Restu Ria Wantika ${ }^{1}$, Reni Tri Anggraini ${ }^{2}$}

mampu menggunakan rumus yang sesuai rencana, namun siswa mampu menjelaskan alur hasil penyelesainnya. Tetapi siswa berkemampuan literasi level-3 ini tidak bisa menemukan cara lain untuk memecahkan masalah. Terakhir siswa mampu menjadi kriteria yang terakhir berpikir kritis yaitu selalu meninjau kembali setiap hasil penyelesaiannya. Jadi, siswa kemampun literasi level-3 mampu mengevaluasi proses berpikirnya sendiri.

\section{B. Saran}

Berdasarkan hasil penelitian dan kesimpulan, Proses berpikir kritis siswa dalam Penyelesaian Permasalahan Matematika pada materi persamaan garis lurus menunjukkan bahwa siswa belum dapat melakukan penyelesaian permasalahan dalam bentuk soal yang menggunakan cara atau rumus yang lebih dari satu. Siswa hanya mampu mengerjakan dengan pengetahuan yang telah diberikan dan siswa belum dapat menemukan cara penyelesaian permasalaha dengan cara yang lainnya. Oleh karena itu, dalam pembelajaran matematika guru tidak hanya mengajarkan rumus - rumus saja tetapi memberikan masalah atau latihan soal-soal yang memiliki banyak cara dan berbagai model soal agar kemampuan berpikir kritis siswa dalam menyelesaiakan permasalahan matematika dapat berkembang.

\section{DAFTAR PUSTAKA}

Cahyono, B. (2017). Analisis Keterampilan Berpikir Kritis dalam Memecahkan Masalah ditinjau Perbedaan Gender. Aksioma: Jurnal Matematika Dan Pendidikan Matematika, 8(1), 50-64.

Holis, M. N., \& Sahidin, L. (2016). Deskripsi Kemampuan Literasi Matematika Siswa SMP di Kabupaten Konawe. JPPM (Jurnal Penelitian Dan Pembelajaran Matematika), 4(2), 141-152. https://doi.org/http://dx.doi.org/10.36709/jppm.v4i2.3070

Maulana, M. (2017). Konsep Dasar Matematika dan Pengembangan Kemampuan Berpikir Kritis Kreatif. Sumedang: UPI Press.

Nisa, R. (2016). Profil Berpikir Kritis Siswa SMP dalam Menyelesaikan Soal Cerita Ditinjau dari Gaya Kognitif dan Kemampuan Matematika. APOTEMA: Jurnal Program Studi Pendidikan Matematika, 2(1), 66-76.

Styawati, R. D., \& Nursyahida, F. (2017). Proses Kemampuan Literasi Matematika Siswa Berkemampuan Matematis Rendah dalam Menyelesaikan Soal Berbentuk PISA. Aksioma: Jurnal Matematika Dan Pendidikan Matematika, 8(2), 33-42.

Sugiyono. (2017). Metode Penelitian Kuantitatif, Kualitatif, dan R\&D. Bandung: Alfabeta. 
Histogram: Jurnal Pendidikan Matematika, 3 (2), 2019 - 275 Restu Ria Wantika ${ }^{1}$, Reni Tri Anggraini ${ }^{2}$

Ulya, H. (2016). Proses Kemampuan Pemecahan Masalah Siswa Bermotivasi Belajar Tinggi Berdasarkan Ideal Problem Solving. Jurnal Konseling Gusjinjang, 2(1), 9096. https://doi.org/http://dx.doi.org/10.24176/jkg.v2i1.561 